\title{
STUDY OF CUSTOMER SATISFACTION AT CANTEEN OF SAHID UNIVERSITY - JAKARTA
}

\author{
Intan Nurul Azni, Giyatmi, Julfi Restu Amelia \\ Universitas Sahid, Indonesia \\ intanurulazni@gmail.com
}

\begin{abstract}
The canteen of Sahid University - Jakarta is a canteen which is located at Prof. Dr. Soepomo, SH No. 84, Tebet South Jakarta. The counters were sheltered by the Employee Union of Sahid University - Jakarta. The canteen of Sahid University - Jakarta is able to accommodate 15 counters for catering business. Currently the food and beverage products sold in the canteen are still in conventional method so that consumers are limited to the academic community of Sahid University - Jakarta and the community around the campus. This study aimed to assess the services offered by the canteen. This study also to determine the level of satisfaction of canteen customers on the canteen services, and to identify the problems encountered on the services. Most of customer of this canteen are 16-25 years old (84\%) and half number of visitors are senior high school educational background (50\%). More than half number of visitors come to Sahid University - Jakarta ocassionally (58\%). At the quality of products data, more than half number of customers feel satisfied with the taste, price, and portion of foods and drinks are sold at canteen while more than half number of customers don't feel satisfied with the hygiene, variation, and product display. At the quality of service data, more than half number of customers don't feel satisfied with the affordability, convenience, supporting facilities, sanitation, accessibility and waiter's tidiness of canteen. But more than half customers feel satisfied with waiter's politeness, safety feeling, speed of service, accuracy, and seller's the responsiveness of canteen of Sahid University - Jakarta.
\end{abstract}

Keywords: Canteen, Customer Satisfaction; Food Service; Quality Of Product, Quality Of Service

\section{INTRODUCTION}

A canteen is a place where foods and drinks are sold. Every canteen has the responsibility to provide the quality foods with proper service and good hygiene practice to the customer (Galabo, 2019). In Sahid University - Jakarta which is located at Jalan Prof. Dr. Soepomo, SH No. 84, Tebet South Jakarta, has a canteen that sell the foods and drinks. The counters were sheltered by the Koperasi Karyawan of Sahid University - Jakarta.

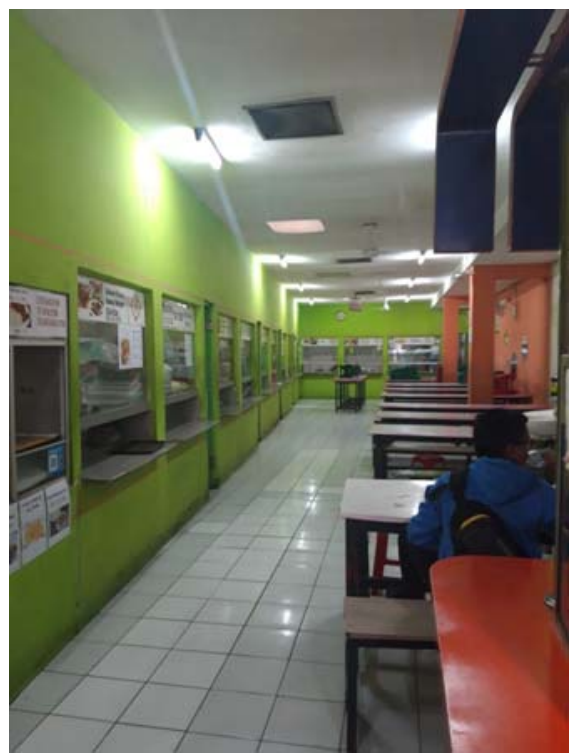

Picture 1. Canteen of Sahid University - Jakarta

Customer's satisfaction is an important key for the economy sector. The service of canteen is important in developing interest in buying nutritious and healthy food among customer, making it possible for them to enjoy nutritious and healthy food at affordable prices during the day. The canteen should also provide the customer variety of foods and dishes. The aim of this study are to assess the service of canteen by measuring the the level 
of customer satisfaction, to identify the service problems, and proposed plan of action to solve the problems (Labay, 2015).

Customer satisfaction is a customer's perspective based on expectation and then post purchase experience. Customer satisfaction is an evaluation of products or services quality level that fulfill the customer expectations. Satisfaction means the feeling an individual gets when his or hers wishes, expectations or needs are fulfilled, and the pleasant feeling that follows from it (Galabo, 2019).

This study aimed to assess the services offered by canteen of Sahid University - Jakarta. This study also to determine the level of satisfaction of canteen customers on the canteen services, and to identify the problems encountered on the services.

\section{METHODS}

The research design that was used in this research was a descriptive method. In order to support this study, a total of fifty (50) respondents are given a questionnaire that contains some questions about the canteen's service. The respondents are the canteen's customers. Beside that the researchers also collect datas about type foods that are sold at canteen of Sahid University - Jakarta.

The questionnaire divided into two parts. The first one contains the demographics data such as gender, age, level of education, occupation, and the visiting's frequency. The second part contains the level satisfaction of canteen's service question. The level satisfaction questions were categorized into two subtopics: quality of products and quality of service. The respondents were asked to choose 5 level of satisfaction (highly satisfied $=1$, satisfied $=2$, slightly satisfied $=3$, less satisfied $=4$, and not satisfied $=5$ ) on each question. After the questionnaire has been collected, the answers were tabulated by microsoft excell program and analyzed. The datas are written dwon into graphics and table.

\section{RESULTS AND DISCUSSION}

\section{Canteen of Sahid University - Jakarta profile}

Canteen of Sahid University - Jakarta has 15 counters for catering service businesses. They are Seblak; Tahu Bulat; Siomay, Batagor, Meet balls; Chicken Noodle; Gudeg Rice; Soto; Minangnese Cuisine; Fried Rice and Fried Noodle; Duck Rice; Grilled Chicken and Gado-gado; Rames Rice; Fried Chicken; Katsu and Crispy Chicken; Pempek; Pecel ayam and Lele; Juices (Picture 2). The counters were sheltered by the Koperasi Karyawan of Sahid Jakarta University. The canteen Sahid of University - Jakarta is located at the back of campus and has an area of $6 \times 11 \mathrm{~m}$. The canteen operates every Monday-Saturday from 07.00-20.00. The customers of food service products at the Sahid University canteen currently are generally the students of the Sahid University and the community around the campus.

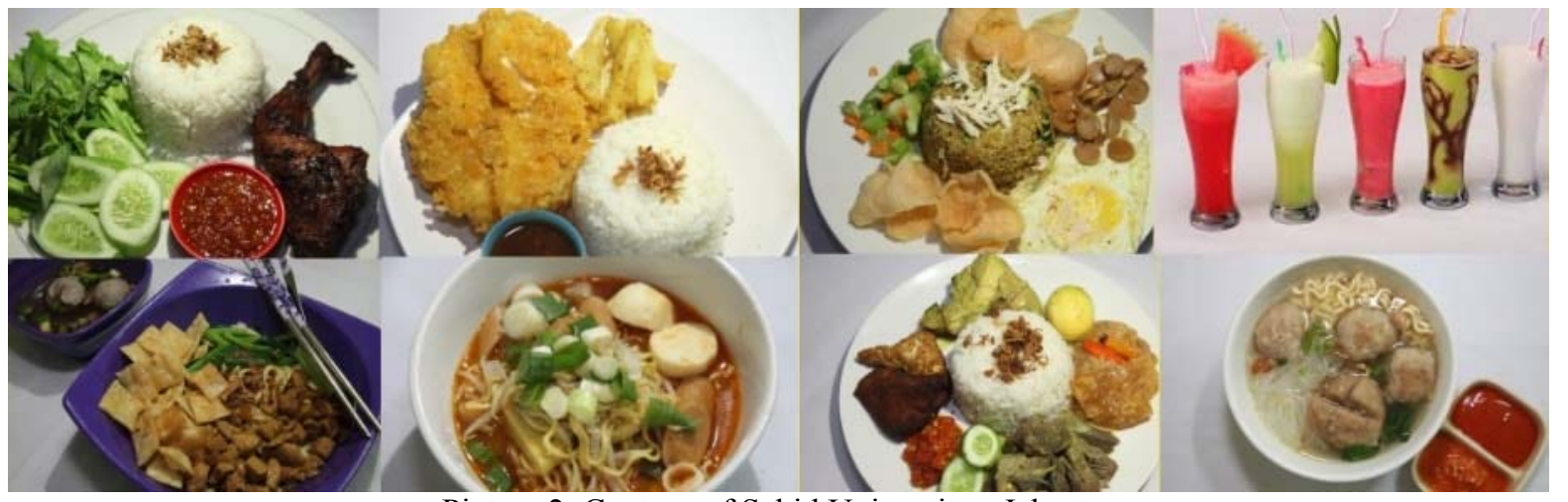

Picture 2. Canteen of Sahid University - Jakarta menu

\section{Customer's profile}

From 50 customers of canteen of Sahid University, the $90 \%$ visitors are women. Most of customer are 16-25 years old (84\%) and half visitors are senior high school educational background (50\%). More than half of visitors are the students of Sahid University - Jakarta (68\%). More than half number of visitors come to Sahid University Jakarta ocassionally (58\%). The visitor of Sahid Jakarta Profile can be seen at Picture 3. 


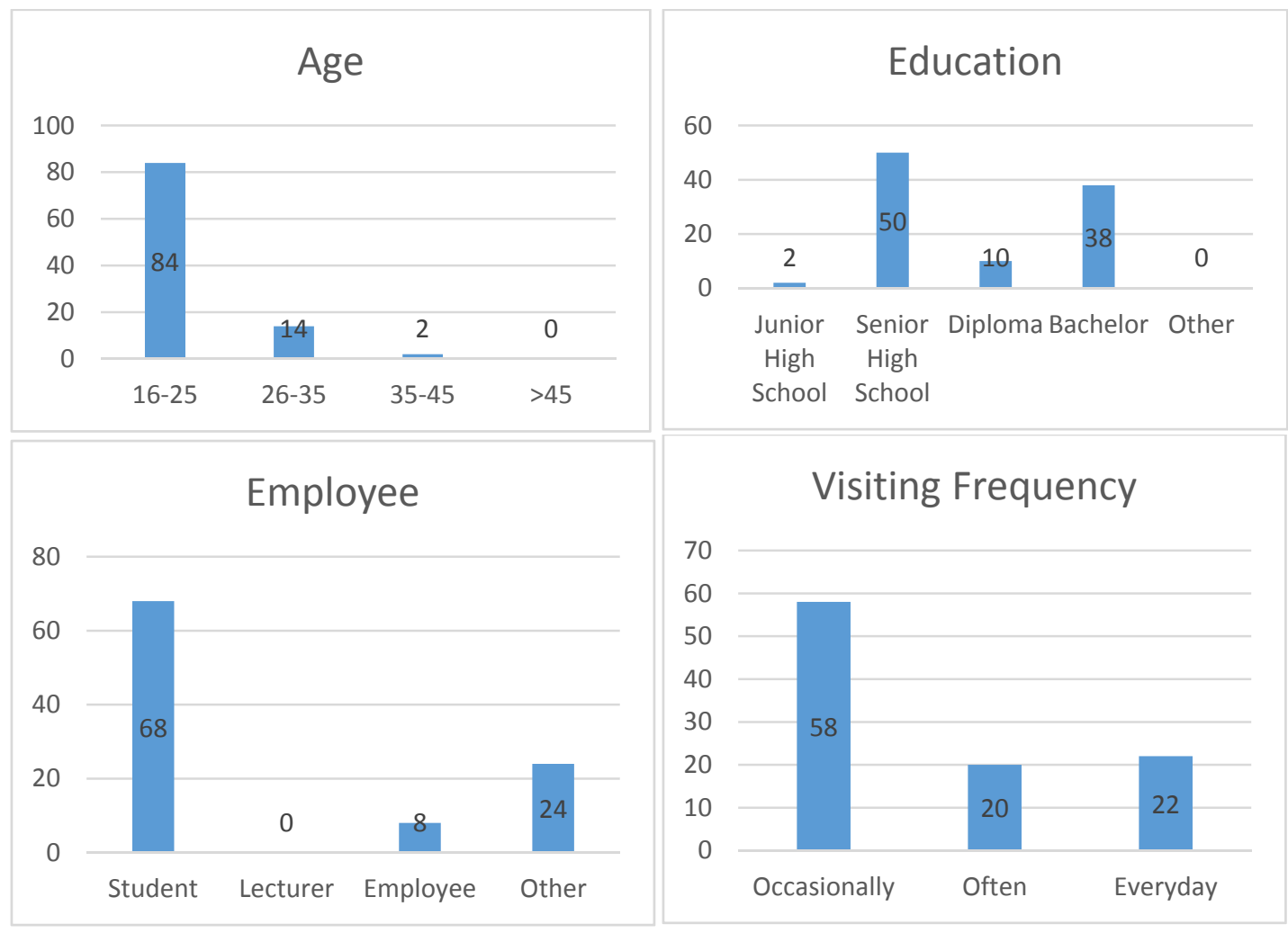

Picture 3. Profile of customer of Sahid University canteen

\section{Customer's level of satisfaction}

Tabel 1 present the distribution the customer's level satisfaction of Sahid University canteen service. The data is divided into two catagories. The first catagory is the quality of products with the taste, price, hygiene, portion, variation, and product display atributes. The second catagory is the quality of service with the affordability, convenience, supporting faculities, sanitation, accessibility, waiter's tidiness, waiter's politeness, safety, speed of service, accuracy, and responsivenes atributes.

The concept of quality is difficult to define since quality means different things to different people. In other words, the way one customer experience of a product or service is not the same way another people will experience it. Quality can be categorized in terms of various perspectives like judgement of product. With the judgment perspective, the quality of a product cannot be defined but can be recognized. The user perspective is about how the needs of a customer are fulfilled (Evans, 2011).

At the quality of product data, more than half number of customers feel satisfied with the taste of foods and drinks are sold at Sahid University canteen (52\%). Forty two percent customers satisfied of food's price. Sixty percent customers feel satisfied with the food portion Less than half customers feel satisfied of variation and product display (Table 1). According to them, the foods that are sold don't have any different from other store. They expect some unique foods are sold at Sahid University canteen.

Only 30\% customers feel satisfied and highly satisfied about the hygiene of foods (Tabel 1). Hygiene is the most important aspect in food service. Because it related to food safety. There are many factors attributed to make food unsafe such as: sources of raw materials, process of foods, the storing and handling method, and also the people who involved in the process (Manzano, 2013). The unhygiene of food handling can cause foodborne disease. In Sahid University - Jakartacanteen, the customers satisfaction level of hygiene still less than $50 \%$. This case needs attention from the food handler of Sahid University canteen. 
Table 1. Level of satisfaction on the canteen of Sahid University services

\begin{tabular}{|c|c|c|c|c|c|c|}
\hline \multirow[t]{2}{*}{ No } & \multirow[t]{2}{*}{ Items } & \multicolumn{5}{|c|}{ Level of Satisfaction (\%) } \\
\hline & & $\begin{array}{l}\text { Highly } \\
\text { Satisfied }\end{array}$ & Satisfied & $\begin{array}{l}\text { Slightly } \\
\text { Satisfied }\end{array}$ & $\begin{array}{c}\text { Less } \\
\text { Satisfied }\end{array}$ & Not Satisfied \\
\hline & Quality of Products & & & & & \\
\hline 1 & Taste & 6 & 52 & 36 & 4 & 2 \\
\hline 2 & Price & 18 & 42 & 34 & 6 & 0 \\
\hline 3 & Hygiene & 8 & 22 & 52 & 16 & 2 \\
\hline 4 & Portion & 8 & 60 & 30 & 2 & 0 \\
\hline 5 & Variation & 10 & 32 & 36 & 16 & 6 \\
\hline 6 & Product display & 10 & 26 & 46 & 14 & 4 \\
\hline & Quality of Services & & & & & \\
\hline 1 & Affordability & 24 & 44 & 26 & 4 & 2 \\
\hline 2 & Convenience & 4 & 14 & 42 & 30 & 10 \\
\hline 3 & $\begin{array}{l}\text { Supporting facilities (wifi, } \\
\text { prayer room, parking area) }\end{array}$ & 6 & 22 & 42 & 20 & 10 \\
\hline 4 & Sanitation & 4 & 22 & 44 & 24 & 6 \\
\hline 5 & Accessibility & 12 & 32 & 38 & 16 & 2 \\
\hline 6 & Waiter's tidiness & 8 & 30 & 46 & 16 & 0 \\
\hline 7 & Waiter's politeness & 18 & 52 & 24 & 6 & 0 \\
\hline 8 & Safety & 14 & 42 & 38 & 6 & 0 \\
\hline 9 & Speed of service & 14 & 42 & 40 & 4 & 0 \\
\hline 10 & Accuracy of ordered food & 18 & 50 & 28 & 4 & 0 \\
\hline 11 & Responsiveness & 10 & 52 & 32 & 4 & 2 \\
\hline
\end{tabular}

At the quality of service data, $44 \%$ customers feels satisfied with the affordability of Sahid University canteen. Less than half customers feel satisfied with the convenience, supporting facilities, sanitation, accessibility and waiter's tidiness of Sahid University canteen. But more than half customers feel satisfied with waiter's politeness, safety feeling, speed of service, accuracy, and seller's the responsiveness of Sahid University canteen (Table 1).

Some customers don't feel satisfied to buy foods in canteen because there are some cats in canteen and also there are some customers who smoke in canteen even though there is written rule about smoking prohibition. Another customers don't feel satisfied to buy food in canteen because the room is pretty hot since there isn't air conditioner in canteen.Inadequate canteen area also causes low customer satisfaction in the canteen. Some customers come from the community around the Sahid University. This cause the students of this campus can't get the seat to eat.

\section{CONCLUSION}

The customers of food service products at the Sahid University canteen are generally the students of the Sahid University - Jakarta and the community around the campus. Most of customer are 16-25 years old and half number of visitors are senior high school educational background. More than half number of visitors come to Sahid University ocassionally. At the quality of products data, more than half number of customers feel satisfied with the taste, price, and portion of foods and drinks are sold at Canteen of Sahid University while more than half number of customers don't feel satisfied with the hygiene, variation, and product display. At the quality of service data, more than half number of customers don't feel satisfied with the affordability, convenience, supporting facilities, sanitation, accessibility and waiter's tidiness of Canteen of Sahid University. But more than half customers feel satisfied with waiter's politeness, safety feeling, speed of service, accuracy, and seller's the responsiveness of Canteen of Sahid University - Jakarta.

\section{REFERENCES}

1. Evans JR. (2011). The management and control of quality (Edisi ke-8.). South-Western-Cengage Learning (USA).

2. Galabo NR. (2019). "Canteen service quality and student satisfaction”. International Journal of Scientific \& Technology Research, 8(6),114-26.

3. Labay DJR, Macuha ERD, Mondragon HAO, Sarmiento AKE, Veron MRB, Salazar L, Caiga BT. (2015). "Maritime student's satisfaction on the service rebdered by the canteen". Asia Pacific Journal of Maritime Education, 1(1),7-12. 
4. Manzano AI. (2013). "Competency-based modules in food sanitation and safety". International Journal of Academic Research in Business and Social Sciences, 3(8),142-55. 